\title{
ENHANCING SERVICE PRODUCTION AND SERVICE QUALITY
}

\author{
KRISHNA GOVENDER \\ Faculty of Business Management \\ Technikon Witwatersrand
}

\begin{abstract}
This article sheds light on a possible strategy to enhance service production and service quality by reporting on an exploratory mail survey conducted among a sample of 1000 commercial bank customers. It became apparent that by using formal and informal strategies to socialize their customers, service providers could positively influence their customers' perception of service quality. However, although both formal and informal socialization strategies are significantly correlated with the role ambiguity and the role conflict experienced by customers, the role ambiguity and role conflict experienced by service customers did not significantly influence their perception of service quality.
\end{abstract}

\section{OPSOMMING}

Hierdie artikel werp lig op'n moontlike strategie om diensproduksie en -kwaliteit te bevorder deur die rapportering van'n eksploratiewe pos-opname onder' $n$ steekproef van 1000 handelsbankkliënte. Dit het duidelik geword deur die gebruik van formele en informele strategieë om kliënte te sosialiseer dat diensverskaffers hulle kliënte se persepsie van dienskwaliteit positief kon beïnvloed. Beide die formele en die informele sosialiseringstrategieë is beduidend gekorreleerd met rolonsekerheid en rolkonflik soos deur kliënte ervaar, maar die ervaarde rolonsekerheid en rolkonflik het nie hulle persepsie van dienskwaliteit betekenisvol beïnvloed nie.

Since service customers often take on the role of 'partial' employees (Wikstrom, 1996) during the service encounter, it is important for service organization to ascertain what management practices could be used to ensure that the customers have the competencies to perform their role as co-producers of the service. Zeithaml, Parasuraman and Berry (1990) suggested a number of ways by which the service performance gap could be closed, interalia, the provision of role clarity in job descriptions and quality standards, and informing employees about what is expected of them. These suggestions imply the need for organizational socialization of service employees. Due to the participatory nature of the role played by the service customers, that of a partial employee, Kelley, Skinner and Donnelly (1990) suggested that the process of socialization might also be considered as a useful strategy to provide role clarity for customers. Since the active role of partial' employee (played by service customers) results in the introduction of uncertainty in the service production process, the process of organizational socialization may assist in reducing customer induced' uncertainty.

Researchers (Starr \& Fondas, 1992) assert that socialization tactics influence the role orientations that newcomers ultimately adopt. Van Maanen and Schein (1979) identified various socialization tactics or strategies, which include collective versus individual socialization, sequential versus random, fixed versus variable, guided versus unguided, formal versus informal, and investive versus divestive. Ashforth and Saks (1996) remark that despite the cogency of this typology, research on the tactics has been relatively scarce. This paper attempts to address the remark by reporting on the effects of formal and informal organizational socialization tactics on service customers' perception of their roles, and service quality.

Formality is the degree to which socialization takes place apart from the ongoing work of the organization. Through formal socialization, employees (customers) are separated from others while they learn about the organization and their tasks (Wagner \& Hollenbeck, 1996). During informal socialization, employees (customers) interact with more experienced employees (customers), become integrated into the organization, and learn on the job. Thus formal socialization allows the employees (customers) to see and learn what the organization wants them to learn, whereas informal socialization allows employees (customers) to experience the organization on their own terms.

\section{Organizational Socialization - Service Quality}

Solomon, Surprenant, Czepiel \& Gutman (1985) propose that when customers and employees "read from a common script", the service encounter will be more satisfying to both. This implies that the socialized customer should be more satisfied because his or her service expectations more closely approximate the actual service provided. To explore this relationship further, it is hypothesized that:

H1: Formal [FS] and Informal [IS] organizational socialization of service customers is positively associated with the overall Service Quality [SQUAL] as perceived by customers.

The literature also suggests that the effects of organizational socialization on service quality is indirect or mediated through other variables, inter-alia, the customers' role perception. This apparent relationship was explored further.

\section{Organizational Socialization - Role Perception}

Researchers (Singh, Vebreke and Rhoads, 1996) agree that when an individual has gained an appropriate understanding of his or her role and the roles of the other members of the role set, it is possible to formulate accurate role expectations. Furthermore, Schneider and Bowen (1995) assert that in order for service employees [and service customers] to learn their roles and be able to form accurate role expectations for the service encounter, they must be formally socialized into the organization. In view of the aforementioned, it is proposed that:

H2: Formal organizational socialization of the service customer is negatively associated with Role Ambiguity [RA] and Role Conflict [RC] experienced by the customer.

H3: Informal organizational socialization of the service customer is positively associated with Role Ambiguity and Role Conflict experienced by the customer.

\section{Role Perception - Service Quality}

Hartline and Ferrel (1993) suggest that role ambiguity affects service employees' performance which may spill over to the perceptions of service quality on the part of the customers. In order to explore the relationship between service quality and the customers' role perception, the following hypothesis is proposed:

H4: The level of Role Conflict and Role Ambiguity experienced by the service customers is negatively associated with their perception of Service Quality.

Researchers such as Behrman and Perreault (1984) have found that role conflict and role ambiguity as perceived by the service employee are positively correlated. In order to explore the relationship between role conflict and role ambiguity as it pertains to the service customer, it is hypothesized that: 
H5: The Role Ambiguity experienced by service customers is positively associated with the Role Conflict experienced by customers.

\section{METHOD}

\section{Sample and Sampling Procedure}

A combination of convenience and judgmental sampling was employed to select bank employees to distribute questionnaires to a random sample of 1000 bank customers, by taking cognizance of the comments of Churchill (1995) regarding sample selection and sample size. These front-line employees distributed questionnaires to every third customer with whom they interacted for at least five minutes. The rationale for choosing every third customer was to introduce a "sense of randomness" into the sample, a procedure which has been endorsed by researchers such as Danaher and Mattsson (1993) and Naumann and Giel (1995). A covering letter explaining the purpose of the research, as well as stamped, addressed envelopes were provided so that completed questionnaires could be forwarded directly to the researcher.

\section{Measuring Instruments}

The type of organizational socialization as perceived by the bank customers was measured with a 5 point Likert scale with anchors of (1) strongly disagree, (2) disagree, (3) neither agree nor disagree (neutral), (4) agree, (5) strongly agree. A 5 -point scale was used because the pre-test revealed that respondents could not make fine mental distinctions with respect to whatever was being measured. The questions which attempted to determine the type of organizational socialization were adapted from the questionnaire developed by Jones (1986). The questionnaire comprised of a 9-item instrument, four of which attempted to measure "Formal" socialization.

The conflict and ambiguity scales developed by Chonko, Howell, and Bellenger (1986) were adapted for this research. In order to ascertain information about role conflict, service customers were asked to indicate the agreement between themselves and their banks on a 5 point scale ranging from 1 (no agreement) to 5 (complete agreement). This section of the questionnaire consisted of 2 items. For the role ambiguity scale, bank customers were asked to indicate how certain they were about each of 6 items using a scale ranging from 1 (completely uncertain) to 5 (completely certain).

Since, recent research (Buttle, 1996; Nel, Pitt \& Berthon, 1997) uncovered a number of deficiencies in the SERVQUAL scale, an alternative scale [named SQUAL], based on the 22-items of the SERVQUAL instrument was used in this study. The SQUAL scale combined expectations and perceptions into one measure by asking customers whether certain aspects of service quality exceeded or fell short of expectations. This approach which was adopted by Hartline and Ferrel (1993) was recommended by Parasuraman et al. (1994). Bank customers were asked to rate each of the 22 items on a scale ranging from 1 (worse than expected) to 5 (better than expected).

\section{Statistical Analysis}

To empirically evaluate the hypothesized relationships the computer programme RAMONA (Brown \& Mels, 1990) was used. RAMONA which is an improvement on LISREL, not only tests for significant deviations from zero for all parameters, but also provides for measures of fit of the data to an hypothesized model. By specifying an analysis based on sample correlation matrix with maximum likelihood estimation, the research model was fitted to the observed data.

\section{RESULTS}

After three months, only 190 usable questionnaires were received. This response rate of 19 per cent could be attributed to the research method, since customers could not be "forced" to complete and return the questionnaires. Furthermore, employees were unable to trace the customers to whom they had given questionnaires, since this was done randomly. As a follow-up, branch managers were requested to display notices requesting customers to complete and return the questionnaires to the researcher.

The majority $(66 \%)$ of the customers indicated that they were with the same bank for over 5 years. An overwhelming majority $(83 \%)$ of the customers indicated that they were satisfied with the service provided by their bank.

The PROC.UNIVARIATE procedure was performed on the research variables using the SAS (SAS Institute 1990) computer programme. Considering that a 5-point scale was used, it is apparent from the preliminary results reflected in Table 1 that the bank customers perceived themselves as being more informally socialized. They also did not experience a great deal of ambiguity and conflict. Furthermore, the overall service quality offered by the banks was perceived as being high.

TABLE 1

DESCRIPTIVE RESULTS [N=190]

\begin{tabular}{lllll}
\hline VARIABLES & MEANS & $\begin{array}{l}\text { STANDARD } \\
\text { DEVIATION }\end{array}$ & SKEWNESS & VARIANCE \\
\hline Formal Socialization & 2.7463 & 0.8146 & -0.1055 & 0.6636 \\
Informal Socialization & 3.0487 & 0.9656 & 0.3738 & 0.9325 \\
Role Ambiguity & 3.7649 & 0.7534 & -1.1213 & 0.5676 \\
Role Conflict & 3.3763 & 1.4167 & -0.8105 & 2.0071 \\
Service Quality & 4.1048 & 0.7946 & -0.9819 & 0.6314 \\
\hline
\end{tabular}

Stepwise Reliability Analysis (Willie, 1996) was performed on the measuring instruments using the computer programme SAS PROC.CORR (SAS Institute, 1990) The process was repeated until all the measuring instruments possessed an acceptable level of reliability as measured by its Cronbach's coefficient alpha (Cronbach, 1951). It is evident from Table 2 that the latent variables were measured with acceptable levels of reliability, since the Cronbach alpha coefficient's exceeded 0.7 , a reliability coefficient favoured by most social scientists.

TABLE 2

RELIABILITY AND VALIDITY

\begin{tabular}{lccccc}
\hline & $\begin{array}{c}\text { Formal } \\
\text { Sterilization }\end{array}$ & $\begin{array}{c}\text { Informal } \\
\text { Sterilization }\end{array}$ & $\begin{array}{c}\text { Role } \\
\text { Ambiguity }\end{array}$ & $\begin{array}{c}\text { Role } \\
\text { Conflict }\end{array}$ & $\begin{array}{c}\text { Service } \\
\text { Quality }\end{array}$ \\
\hline $\begin{array}{l}\text { CRONBACH'S } \\
\text { APLHA }\end{array}$ & & & & & \\
CO-EEFICIENT & 0.807 & 0.847 & 0.861 & 0.886 & 0.966 \\
ITEMS & FACTOR 1 & FACTOR 2 & FACTOR 3 & FACTOR 4 & FACTOR 5 \\
FS1 & 0.057 & $\mathbf{0 . 4 2 7 \star}$ & 0.133 & 0.001 & 0.063 \\
FS6 & 0.052 & $\mathbf{0 . 8 2 9 \star}$ & -0.030 & 0.014 & -0.101 \\
FS7 & -0.012 & $\mathbf{0 . 7 2 1 \star}$ & 0.009 & -0.007 & 0.151 \\
IS5 & -0.079 & 0.049 & $\mathbf{0 . 9 8 0}$ & 0.031 & 0.017 \\
IS9 & 0.115 & -0.051 & $\mathbf{0 . 7 3 2 \star}$ & -0.030 & -0.019 \\
RA2 & 0.062 & 0.015 & -0.033 & $\mathbf{0 . 6 3 8}$ & 0.032 \\
RA3 & -0.014 & -0.014 & -0.018 & $\mathbf{0 . 9 9 2 \star}$ & -0.028 \\
RA4 & -0.054 & -0.011 & 0.122 & $\mathbf{0 . 8 1 3} \star$ & 0.071 \\
RA6 & 0.146 & 0.013 & -0.007 & $\mathbf{0 . 4 3 0 \star}$ & 0.029 \\
RC1 & -0.004 & 0.005 & -0.039 & 0.079 & $\mathbf{0 . 8 4 2 \star}$ \\
RC2 & 0.025 & 0.025 & 0.029 & -0.017 & $\mathbf{0 . 8 9 9 \star}$ \\
SQ1 & $\mathbf{0 . 8 4 1 \star}$ & 0.053 & 0.020 & 0.085 & -0.033 \\
SQ2 & $\mathbf{0 . 9 2 4 \star}$ & -0.036 & 0.048 & 0.022 & 0.013 \\
SQ3 & $\mathbf{0 . 8 4 7 \star}$ & 0.025 & 0.090 & -0.039 & 0.068 \\
SQ4 & $\mathbf{0 . 9 4 4 \star}$ & 0.026 & -0.013 & -0.020 & -0.001 \\
\hline
\end{tabular}

^ factor loadings $>0.4$ were considered significant

As an initial step to address the question of validity, the measure development paradigms recommended by Parasuraman (1991) was closely followed during the development of the scales. Thereafter, Stepwise Exploratory Factor Analysis (Willie, 1996) was performed to ascertain the discriminant and construct validity of the measuring instruments. In each step of the analysis, BMDP4M (Frane, Jennrich \& Sampson, 1993) was used to perform a maximum likelihood factor analysis with a direct quartimin rotation (Jennrich \& Samp- 
son, 1966) of the unrotated factor matrix. It is evident from Table 2 that the measuring instruments possessed acceptable levels of discriminant and construct validity since they load heavily only on one factor, with loadings above 0.4 (Rummel, 1967).

The research model was fitted to the observed data by specifying an analysis based on the sample correlation matrix with maximum likelihood estimation. The resulting maximum likelihood estimates with their associated significance information in terms of $p$ values are reflected in Table 3 . In this table, a T-value greater than $1.96(\mathrm{p}<0.05)$ or a T-value greater than 2.58 ( $\mathrm{p}<0.01)$ implies a significant influence. T-values which are equal to or less than 1.96 ( $\mathrm{p}>0.05)$ implies a non-significant influence. Based on the findings, Table 3 also reflects the decision on the various hypotheses.

TABLE 3

SUMMARY OF EMPIRICAL FINDINGS

\begin{tabular}{|c|c|c|c|c|c|}
\hline РATH & SPE & P-Values & T-Values & $\begin{array}{l}\text { Hypothesized } \\
\text { Influence }\end{array}$ & Conclusion \\
\hline $\mathrm{FS} \longrightarrow \mathrm{SQUAL}$ & 0.193 & $\ll 0.05$ & 2.54 & Positive & H1-Accepted \\
\hline $\mathrm{IS} \longrightarrow \mathrm{SQUAL}$ & 0.164 & $(0.05$ & 2.35 & Positive & H1-Accepted \\
\hline $\mathrm{FS} \longleftrightarrow \mathrm{RA}$ & 0.281 & $\prec 0.01$ & 3.23 & Negative & H2-Accepted \\
\hline IS $\longleftrightarrow$ RA & 0.344 & «.01 & 4.37 & Positive & H3-Rejected \\
\hline $\mathrm{FS} \longleftrightarrow \mathrm{RC}$ & 0.373 & «.01 & 4.54 & Negative & H2-Rejected \\
\hline $\mathrm{IS} \longleftrightarrow \mathrm{RC}$ & 0.308 & $\prec 0.01$ & 3.85 & Positive & H3-Accepted \\
\hline $\mathrm{RC} \longrightarrow \mathrm{SQUAL}$ & -0.047 & $>0.05$ & -0.63 & Negative & $\mathrm{H} 4-\mathrm{NS}$ \\
\hline $\mathrm{RA} \longrightarrow \mathrm{SQUAL}$ & 0.107 & 0.05 & 1.54 & Negative & H4-NS \\
\hline $\mathrm{RA} \longleftrightarrow \mathrm{RC}$ & 0.555 & «.01 & 8.96 & Positive & H5-Accepted \\
\hline
\end{tabular}

Table 3 shows that contrary to the hypothesized view, both formal and informal socialization experienced by customers exert a significant positive influence on their perception of the overall service quality. Formal socialization and informal socialization are significantly correlated with both the role ambiguity and the role conflict experienced by service customers. This means that the better the formal and informal socialization between the service organization and its customers, the lower will be the level of role ambiguity and role conflict experienced by the service customers and vice-versa.

The measures of fit of the model suggested that the model provided a reasonable fit to the data. The Root Mean Square Error of Approximation (RMSEA) of 0.068 was less than 0.8. Furthermore, the expected cross validation index (CVI) for the model was 3.046, which was less than that for the saturated model, which was given as 3.345 .

The most revealing finding is that, both formal and informal socialization exert a positive influence on the customers' perception of the overall service quality. Previous research (Kelley, 1987) merely supports the hypothesis of a positive relationship between the "level" or "degree" of organizational socialization achieved by the customers and their perception of the service quality. Thus the process of socialization may provide a means of "training" and motivating customers so that the encounter experience is satisfying to them. Moreover, it is apparent that customers are positively socialized [may acquire banking knowledge and skills] by both formal and informal strategies since both (sources) are significantly correlated. Considering that customers interact with other customers during service delivery, it may be assumed that this is a source of "informal" socialization.

However, since it may be difficult to control the information which customers receive from "informal" sources, service organizations should endeavour to provide as much information as possible by way of "formal" sources, for example pamphlets and newsletters.

Since the process of socialization can be controlled to a large extent by the organization, management should ensure that customers are effectively socialized. Through effective formal socialization, it may be possible to manage the service expec- tations of the service customers and indirectly manage their perceptions of service quality. Furthermore, the process of organizational socialization may provide a means for the service organization to help customers develop more accurate role expectations. This would result in customers performing their roles better, which could contribute to the delivery of higher levels of service quality.

\section{CONCLUSION}

Consumer behaviour research on how customers acquire their perception of their consumption and production roles may also benefit service managers trying to develop able 'partial employees.'Although customers are a source of input uncertainty relative to the diversity of their demands and their disposition to participate, the service organization could influence the customers through formal and informal socialization strategies. By managing service customers as human resources and utilizing the information and labour supplied by these customers, the lagging productivity in the service sector could be improved. It is important for the service organization to ascertain what management practices could be used to ensure that the customers have the competencies to perform their role as coproducers of the service.

To increase the generalizability of the findings of this study, future research might involve the replication of this study in a variety of service settings, industries and organizations, and also obtaining data from a larger sample. Furthermore, research on the effects of other socialization tactics could shed more light on not only how management could effectively socialize its service customers, but also which socialization tactics to use.

\section{REFERENCES}

Ashforth, B.E. \& Sacks, A.M. (1996). Socialization tactics: longitudinal effects on newcomer adjustment. Academy of Management Journal, 30(1), 149-178.

Behrman, D.N. \& Perreault, W.D., Jr. (1984). A role stress model of the performance and satisfaction of industrial salespersons. Journal of Marketing, 48 (Fall), 355-377.

Browne, M.W. \& Mels, G. (1990). RAMONA PC user's guide. Unpublished report. Pretoria: Human Sciences Research Council.

Buttle, F. (1996). Is there a role for expectations in SERVQUAL? Working paper no. 294. U.K.: Manchester Business School.

Chonko, L.B., Howell, R.D. \& Bellenger, D.N. (1986). Congruence in sales force evaluations: relations to sales force perceptions of conflict and ambiguity. Journal of Personal Selling and Sales Management, 6, 35-48.

Churchill, G.A., Jr. (1995). Marketing research: methodological foundations. 6th ed. Florida: Dryden.

Cronbach, L.J. (1951). Coefficient alpha and the internal structure of tests. Psychometrika, 16 (3), 297-334.

Danaher, P.J. \& Mattson, J. (1994). Customer satisfaction during the service delivery process. European Journal of Marketing, 28(5), 5-16.

Frane, J., Jenrich, R.I. \& Sampson, P.F. (1990). 4M-factor analysis. In Dixon, W.J. et al. (editors). BDMP statistical software manual. Berkeley: University of California.

Hartline, M.D. and Ferrel, O.C. (1993). Service quality implementation: The effects of organizational socialization and managerial actions on customer-contact employee behaviours. Marketing Science Institute Report No. 93-122. Cambridge, MA: Marketing Science Institute.

Jenrich, R.I. \& Sampson, P.F. (1966). Rotation of simple loadings. Psychometrica, 31, 313-323.

Jones, G.R. (1986). Socialization tactics, self-efficacy, and newcomer's adjustment to organizations. Academy of Management Journal, 29(2), 262-279.

Kelley, S.W. (1987). Managing service quality: The organizational socialization of the service employee and service customer. Unpublished DBA Dissertation. Lexington, Kentucky: University of Kentucky.

Kelley, S.W., Skinner, S.J. \& Donnelly, J.H. (1990). Customer 
participation in service production and delivery. Journal of Retailing, 66(3), 315-335.

Lovelock, C.H. \& and Young, R.F. (1979). Look to customers to improve productivity. Harvard Business Review, 57 (MayJune), 168-178.

Lysonski, S.J. (1982). Behavioural effects of boundary spanning on the product manager. In Walker, B.D., Bearden, W.O., Darden, W.R., Murphy, P.E., Nevin, J.R., Olson, J.C. \& Weitz, B.A., (eds.). An assessment of marketing thought and practice. Chicago: American Marketing Association, Proceedings Series 233-237.

Michaels, R.E. \& Dixon, A.L. (1994). Sellers and buyers on the boundary: potential moderators of role stress-job outcome relationships. Journal of the Academy of Marketing Science, 22(1), 62-73.

Nauman, E. \& Giel, K. (1995). Customer satisfaction measurement and management: Using the voice of the customer. Cincinnati, Ohio: Thompson.

Nel, D., Pitt, L.F. \& Berthon, P.R. (1997). The SERVQUAL instrument: reliability and validity in South Africa. South African Journal of Business Management, 28(3), 113-122.

Parasuraman, A. (1991). Marketing research. 2nd.edition. Massachusetts: Addison-Wesley.

Parasuraman, A., Zeithaml, V.A. \& Berry, L.L. (1994). A reassessment of expectations as a comparative standard in measuring service quality: implications for future research. Journal of Marketing, 58(January), 111-124.

Rummel, R.J. (1967). Understanding factor analysis. Journal of Conflict Resolution, 11, 444-480.
SAS Institute Inc. (1990). User's guide. Release 6.03 ed. Cary, N.C.: SAS Institute Inc.

Schneider, B. \& Bowen, D.E. (1995). Winning the service game. Boston: Harvard Business School Press.

Singh, J., Vebreke, E. \& Rhoads, G.K. (1996). Do organizational practices matter in role stress processes? A study of direct and moderating effects for marketing-orientated boundary spanners. Journal of Marketing, 60(July), 69-86.

Solomon, M.R., Surprenant, C., Czepiel, J.A., \& Gutman, E.G. (1985). A role theory perspective on dyadic interaction: the service encounter. Journal of Marketing, 49 (Winter), 99-111.

Starr, J.A. \& Fondas, N. (1992). A model of entrepreneurial socialization and organization formation. Entrepreneurship: Theory and Practice. US: Baylor University.

Wagner, J.A. \& Hollenbeck, J.R. (1996). Management of organizational behaviour. Englewood Cliffs, New Jersey: PrenticeHall.

Van Maanen, J. \& Schein, E.H. (1979). Towards a theory of organizational socialization. In Research in Organizational Behaviour, Staw, B.M. (editor). Greenwich, CT: JAI.

Wikstrom, S. (1996). The customer as co-producer. European Journal of Marketing, 30(4), 6-19.

Willie G. (1996). A stepwise procedure for the empirical assessment of latent variable models. Unpublished M.Sc. Dissertation. Port Elizabeth: University of Port Elizabeth.

Zeithaml, V.A., Parasuraman, A. \& Berry, L.L. (1990). Delivering quality service: balancing customer perceptions and expectations. New York: The Free Press. 